Thor Swanson has been granted additional leave from the State College of Washington to continue his work as the 1956-57 National Municipal League Staff Fellow. He will resume his duties at the State College in February, 1958.

John Vanderzell, associate professor of government at Franklin and Marshall College, taught at Syracuse University during the past summer session.

P. J. Vatikiotis was a visiting lecturer on Middle East Affairs during special summer program on the Middle Bast, at the School of Advanced International Studies of The Johna Hopkins [Tniversity.

Nicholas Wahl, instructor in government at Harvard University, has recently returned from Saigon, Vietnam where he has served as lecturer in political science at the National
University of Vietnam under the SmithMundt program of the Department of State. He will spend the winter in Paris engaged in research under a Harvard research grant and in the Spring he will serve as lecturer in political science at the University of Jyon under the Fulbright program.

Robert F. Wilcox of the department of political science, San Diego State College, will be on leave during the $1957-58$ academic year. For this period he will serve in a teaching and consultative capacity with the government of Thailand.

Pamela Wrinch, formerly of Wellesley College, has been appointed assistant professor of government at Boston University.

Belle Zeller of Brooklyn College attended the sessions of the American Bar Association in London in August.

\title{
APPOINTMENTS AND STAFF CHANGES
}

Albert L. Alford has been promoted to the rank of assistant professor of government and polities at the University of Maryland.

Roy Alton, formerly of M.I.T., has been appointed assistant professor of political soience at Western Michigan University.

Thornton H. Anderson has been promoted to the rank of associate professor of government and politics at the University of Maryland. During the academic year 1957-1958 he is on leave of absence engaged on a Rockefeller Foundation research grant.

Chester W. Bain, University of Virginia, has been added to the department of political science, West Virginia University.

Benjamin Baker, Rutgers University, has been promoted to associate professor.

Robert J. Batson formerly on the staff of Public Personnel Association has been appointed assistant professor of political science at Western Michigan University.

Norman Wood Beck has been appointed to a full professorship in the social studies depart- ment at Jersey City State Teachers College. During the past year he was and is at present coordinator of the annual conference of college teachers of government and related subjects in New Jersey.

W. Richard Bigger has returned to the department of political science, San Diego State College, where he will assume the duties of coordinator of public administration, replacing Robert F. Wilcox whose three year term has expired.

William J. Block, formerly of The Citadel, Charleston, S. C., has joined the department of history and political science at North Carolina State College with the rank of assistant professor.

Irene Blumenthal has been appointed an instructor in the department of political science at the University of Oregon.

Bernard C. Borning has been promoted from assistant professor to associate professor of political science at the University of Idaho.

Robert Boynton has been appointed to an assistant professorship at the State University of Iowa. 
George A. Brinkley, Jr. has received an appointment as instructor in Columbia College.

Leslie R. Bundgaard, who taught in the University of Maryland program in Europe during the past year, has accepted an appointment as assistant director of the Far East Program of the University of Maryland, with headquarters in Tokyo.

Fred G. Burke has been appointed executive officer of the Arneson Institute of Practical Politics at Ohio Wesleyan University with the rank of assistant professor of political science.

Elbert M. Byrd, Jr. has been appointed to the staff of the department of government and politics at the University of Maryland.

Orin K. Cope has been appointed as lecturer in the department of political science at San 1)iego College.

Claude J. Davis, University of Tennessee has been appointed to the department of political science, West Virginin University.

Lane Davis has been promoted to associate professor at the State University of Iowa. He will resume his duties in September having returned from a year as a fellow at the center for advanced study in the behavioral sciences.

Eugene P. Dverin of the bureau of governmental research at U.C.L.A. has accepted an appointment as lecturer in the department of political science.

David M. Earl has been appointed to the overseas teaching staff of the department of government and politics of the University of Maryland.

Leo M. Egand has resigned from the eity planning staff of Voorhees, Walker, Smith and Smith to accept an appointment as research associate with the Cleveland Metropolitan Services Commission.

Bernard Fall has joined the department of government at Howard University.

John L. Fletcher, Jr. has been promoted to associate professor of government and named associate dean of the graduate achool at Boston University.
Thomas M. Franck, formerly assistant professor of law at the University of Nebraskin has become associate professor in the department of government of New York University.

R. C. Gilkey, University of Minnesota, has joined the department of political science at West Virginia University.

William Griffin, school of public administration at Florida State University, has been appointed assistant professor of government and acting assistant director of the governmental research bureall at the University of South Dakota.

William B. Gwyn has been appointed assistant professor of political science for one year at Bucknell.

William Roy Hanilton, Jr. has been appointed to the staff of the department of government and polities at the University of Maryland.

D. Lincoln Harter resigned his position as assistant professor at the University of Pennsylvania in June, 1957 in order to take a position as assistant to the vice chancellor for planning and development at the University of Buffalo and as director of the office of information services.

John J. Hebal has been appointed to the staff of the department of government and polities at the University of Maryland.

Robert Holt has been promoted to assistant professor at the University of Minnesota.

Abraham Holtzman has received a promotion from the rank of assistant professor to that of associate professor at North Carolina State College.

John A. Huston, chairman of the department of international relations and political science at Knox College has been promoted to the rank of professor.

Irving Howards, formerly of the institute of government and public affairs, University of Illinois, has accepted an appointment as assistant professor of government at Southern Illinois University.

Robert Huckshorn, formerly of U.C.L.A., has been named instructor in the department of social sciences at the University of Idaho. 
Harry $V$. Jaffa has been promoted to the rank of associate professor at Ohio State University.

Henry L. Janssen has been promoted to the runk of associate professor of political science at San Diego State College.

C. Herschel Jones of the political science department at Bucknell has been promoted to professor of political science.

Ned V. Joy has been promoted to the rank of associate professor of political science at Sau Diego State College.

Eli Kaminsky has been appointed as instructor in political science at the University of Florida.

Harry Kantor has been promoted to associate professor at the University of Florida.

Edgar Kemler has joined the department of government at Howard University.

George $C$. Keller has received an appointment as instructor in Columbia College.

Jerome G. Kerwin has been appointed dean of students of the social science division at the University of Chicago.

James D. Kitchen has been appointed an assistant professor of political science at San Diego State College.

Richard Kosaki commenced full-time instruction with the government department of the University of Hawaii as of the fall semester.

Donald B. Leiffer has been chosen chairman of the department of political science, San Diego State College, at the expiration of the three year term of Clarence G. Osborn.

George Manner has been promoted to associate professor at the University of Illinois.

Bruce B. Mason has been promoted to associate professor at the University of Florida.

Duncan MacRae, Jr., was appointed assistant professor in the department of political science at the University of Chicago.

Fred Warner Neal, formerly of the University of California at Los Angeles, has ac- cepted a position as associate professor of international relations and government at the Claremont Giraduate School.

Daniel M. Ogden, Jr., has been promoted to the rank of associate professor at the State College of Washington.

DeVere Pentony has been reappointed to an instructorship in political science at the State University of Iowa.

Lugene S. Powell has been appointed to the overseas teaching staff of the department of government and politics at the University of Maryland.

Hugh Douglas Price has been appointed as instructor in political science at the University of Florida.

Merton L. Reichler has been appointed instructor in political science at Wellesley College.

Edward B. Richards, formerly of Evansville College, has been appointed assistant professor of government at the University of South Dakota. He held a Foundation for Economic Education fellowship during the past summer.

William E. Rhode has been appointed an assistant professor of political science at San Diego State College.

Richard N. Rosecrance, formerly at Brown University, has accepted an appointment as instructor at the University of California (Los Angeles).

Bernard Rubin, Rutgers University, has been promoted to assistant professor.

Alvin $Z$. Rubinstein has been appointed a lecturer in political science at the University of Pennsylvania. He was formerly an associate at the Russian Research Center, Harvard University.

Elmer R. Rusco has been appointed an instructor in political science at San Diego State College.

Mulford Q. Sibley has been promoted to professor at the University of Minnesota.

Phillip Sirotkin, assistant professor of political science at Wellesley College, has ac- 
cepted a position as executive director of the Mental Health Program, Western Interstate Commission of Higher Education.

Clyde F. Snider has been appointed chairman of the department of political science at the University of Illinois.

Joln W. Spanier has been appointed as instructor in political science at the University of Florida.

David Spitz has been promoted to the rank of professor at Ohio State University.

Philip S. Spoerry has joined the staff of the State College of Washington at the rank of instructor following his temporary appointment during 1956-57.

Richard F. Staar has accepted a position as professor of political science and head of the social science department at Arkansas State College.

George Stambuk has been appointed as lecturer in goverument at Indiana University's South Bend Center.
Leo C. Stine has been promoted to professor of political science at Western Michigan University.

Owen Stratton is now chairman of the department of political science at Wellesley College.

James L. Sullivan was appointed instructor in the department of political science at the University of Chicago.

John Turner has been promoted to associate professor at the University of Minnesota.

Fred R. von der Mehden has been appointed assistant professor of political science at the University of Wisconsin.

Joseph Willard, a graduate student in the department of government at Indiana University has been appointed to the faculty of political science at Evansville College.

Larman C. Wilson has been appointed to the overseas teaching staff of the department of government and politics of the University of Maryland.

James S. Young has received an appointment as lecturer in government in Columbia College.

\section{IN MEMORIAM}

James Duff Barnett, professor emeritus of political science and former department head at the University of Oregon, died in Eugene, Oregon, on July 26, 1957. He was born in Cairo, Egypt, on October 25, 1870, a son of missionary parents. The family returned to the United States in 1873 and settled in Emporia, Kansas, where Mr. Barnett graduated from the College of Emporia in 1890. After teaching in the public schools, he attended the University of Wisconsin from which institution he received his doctorate in 1905 . He taught at the University of Oklahoma for several years, after which he accepted a post at the University of Oregon where he served until his retirement in 1941.

He was the author of a number of books, the best known being The Operation of the Initiative, Referendum and Recall in Oregon. For many years he was an editor of the Oregon Law Review and contributed numerous articles to legal and other learned journals. He was a provocative teacher, was interested in civic affairs, and served his city on the Civil Service Commission for a number of terms.

\section{Lucian C. Marvis}

William Bennett Munro, twenty-second president of the American Political Science Association, who died in Pasadena, California, on September 4, 1957 in his 83rd year, was for many years one of the most active and influential members of this Association. Ever ready to do his part in Association work, he served on innumerable committees as well as on the editorial board of the REview. He was a regular attendant at annual meetings from their beginning, and long a valued collaborator in the councils of the leaders of our profession. His text-books on American government and politics went through numerous editions, and were widely used both in this country and abroad. His lectures at Williams, Harvard, and 